\title{
Liparus (Liparus) glabrirostris Küst. AND Hylobius (Callirus) abietis (L.) (COLEOPTERA: CURCULIONIDAE) FIRST RECORDS FOR SERBIA
}

\author{
Snežana B. Pešić \\ University of Kragujevac, Faculty of Science, Department of Biology and Ecology, \\ Radoja Domanovića 12, 34000 Kragujevac, Serbia \\ E-mail: snezana.pesic@pmf.kg.ac.rs \\ (Received March 12, 2021; Accepted May 10, 2021)

\begin{abstract}
This paper presents a survey of data on two weevil species not recorded for the fauna of Serbia till now. Despite their large size, Liparus (Liparus) glabrirostris Küster, 1849 and Hylobius (Callirus) abietis (Linnaeus, 1758) have not been recorded for Serbia in the newest Palaearctic weevil catalogue (ALONSO-ZARAZAGA et al., 2017) or in the Fauna Europaea (AlONSO-ZARAZAGA et al., 2013, https://fauna-eu.org/). In this paper L. glabrirostris, found in a single locality on Mt Goč, is registered as the third representative of the genus Liparus Olivier, 1807 in Serbia. Hylobius abietis is a serious, widely distributed conifer pest, but was not faunistically registered for Serbia till now. Some ecological data and distribution maps with Serbian locations are given for both species.
\end{abstract}

Keywords: large size weevils, fauna, first records, ecological data, large pine weevil, Serbia, Petasites hybridus.

\section{INTRODUCTION}

Entomological collections are important sources of information and very often sources of interesting discoveries, like the two in this paper. Comparison of different findings, i.e., personal weevil collection, and one old, student's entomological collection, with literature sources about the weevil fauna registered so far in Serbia (AlONSO-ZARAZAGA et al., 2017) gave a chance to write this paper about Serbian findings of two weevil species, characterized by large bodies - Liparus (Liparus) glabrirostris Küster, 1849 and Hylobius (Callirus) abietis (Linnaeus, 1758).

Although one of the largest European weevils (with body up to $19 \mathrm{~mm}$ long), $L$. glabrirostris has not been recorded for Serbia so far. It is not listed for our country either in the Fauna Europaea database (ALONSO-ZARAZAGA et al., 2013, https://fauna-eu.org/), or in the latest Catalogue of Palaearctic weevils (ALONSO-ZARAZAGA et al., 2017). This is also true for $H$. abietis (Linnaeus, 1758), a well-known and widely distributed forest pest.

In this paper data on findings of these species with ecological notes for both are given. 


\section{MATERIAL AND METHODS}

Very different entomological field surveys conducted throughout entire Serbia from 1995 onwards by Vesna Stojanović, Ivo Karaman, Nastas Ilić, Snežana Pešić, Dejan Stojanović, Ivan Tot and Mihailo Vujić resulted in the collection of 31 weevil specimens on which this text is based.

Specimens collected by Nastas Ilić (Tab. 1) were in pit-fall traps with $9 \%$ alcoholic vinegar aromatized with rum extract as an attractant, while all other beetles were collected manually or, more rarely, by the classic entomological net.

For the identification of beetles, a series of keys was used: REITTER (1916), HOFFMANN (1954), SMRECZYŃSKI, (1968), ANGELOV (1976), FREUDE et al. (1983), ZAHRADNIK and Severa (2000), Lompe (2013, 2018), SkUHROVEC et al. (2013) and GERMANN et al., 2018.

\section{Liparus (Liparus) glabrirostris Küster, 1849}

The data presented in this paper concern two male specimens. One comes from the insectarium of a? student Vesna Stojanović and was collected on 01.06.1997 on Goč Mt. in Central Serbia (Fig. 2), situated in the northern part of Kopaonik's branch of the Dinaric Alps. Due to doubts about the reliability of the label data, this finding has not been published till now ${ }^{1}$. The second specimen was hand-collected by the author during the XI Symposium of Entomologists of Serbia, on 18.09.2017, again on Goč Mt., at the Dobre Vode locality on a Petasites hybridus leaf.

\section{Hylobius (Callirus) abietis (Linnaeus, 1758)}

There are 29 specimens (4 males, 15 females and 10 unsexed) of $H$. abietis from Serbia in the weevil collections at the Faculty of Sciences, University of Kragujevac, and in the „Fruška Gora” National Park.

Six specimens were already mentioned in published papers: Tara Mt., Kaluđerske Bare, 04.05.2002, 1 q, leg. Snežana Pešić (PEŠIĆ, 2002); Fruška Gora Mt., Ledinci, 21.07.2002, 1, leg. Dejan Stojanović; Fruška Gora Mt., Paragovo Polje, 18.05.2006, 4, leg. Dejan Stojanović (PEŠIĆ et al., 2017; database HABIPROT, 2014-2020).

New records are: Zlatibor Mt., Tornik, $1300 \mathrm{~m}$ a.s.1., 08.07.1995, 1 q, leg. Ivo Karaman; Zlatibor Mt., 23.05.1997, 1 §ิ, leg. Nastas Ilić; Tara Mt., Zaovine, 24.05.1997, 3; 24.05.1999, 1 q, leg. Nastas Ilić; Tara Mt., Kaluđerske Bare, 31.05.1998, 1 \%; 04-24.07.1998, 1 q, leg. Nastas Ilić; Golija Mt., Rudno 1150 m a.s.1., 08.06-02.07.2012, 1 q; 02-30.07.2012, 2, leg. Nastas Ilić; Šar planina Mt., Durlov potok 1600 m a.s.1., 15.07.1997, 1 q, leg. Nastas Ilić; Rtanj Mt., village Rtanj 640 m a.s.1., 18-27.06.2012, 2 + 0 ; 27.06-07.07.2012, 1 §’; 18 27.06.2012, 2 + $\bigcirc$; 19.05-02.06.2019, 1 ; 15.06-01.07.2019, 1 , leg. Nastas Ilić; Vlasina, Vlasina Rid, 20.05.2017, 1 q, leg. Mihailo Vujić; 27.05.2018, 1 đ̆, leg. Snežana Pešić; 26.05.2019, 1 o, leg. Ivan Tot; Vlasina, Čemernik, Cvetkova reka, 27.05.2019, 1 ô, leg. Ivan Tot and Mihailo Vujić.

\section{RESULTS AND DISSCUSION}

\section{Taxonomic position}

Family Curculionidae Latreille, 1802

Subfamily Molytinae Schoenherr, 1823

Tribe Molytini Schoenherr, 1823

\footnotetext{
1 The data were only orally presented at the XII Symposium of Entomologists of Serbia with International Participation, 2017.
} 


\section{Subtribe Molytina Schoenherr, 1823 \\ Genus Liparus Olivier, 1807 \\ Liparus (Liparus) glabrirostris Küster, 1849}

Liparus (Liparus) glabrirostris is one of 16 European species and subspecies in the subgenus Liparus. Nine species are recorded in the countries neighbouring to Serbia (AlONSO-ZARAZAGA et al., 2017).

The genus Liparus includes the largest European weevils $(9-20 \mathrm{~mm})$, with rudimental flight wings, covered with sensors (ZACWILICHOWSKI, 1931, cited after NAZARENKO, 1996). Their black and shiny body has yellow spots of scales, or, less frequently, is bare. These weevils mostly inhabit xerothermic alpine habitats or wet mountain forests. Their feeding plants belong to the families Asteraceae (genera Petasites and Cirsium) and Umbelliferae (=Apiaceae: genera Angelica, Anthriscus, Chaerophyllum, Daucus, Falcaria, Heracleum, Laserpitium, Pastinaca, etc.). Larvae develop in roots / rhizomes (FrEUDE et al., 1983).

Liparus glabrirostris (the great butterbur weevil, or the great weevil) is the largest weevil species in Central Europe, with body 14-21 mm long (REITTER, 1923; FREUDE et al., 1983; ZAHRADNIK and SEVERA, 2000). It is recognizable among the other Liparus species by a Y-forked stripe of yellow scales on the sides of the pronotum.

Adults are active on butterburs (Petasites hybridus, $P$. albus), Cirsium oleraceum and Heracleum pyrenaicum from April to August, and again in November, while larvae develop in Petasites rhizomes (SMRECZYŃSKI, 1968; NAZARENKO, 2001; LOMPE, 2018).

This species inhabits mountains from their bottom to $2000 \mathrm{~m}$ a.s.l., from the Pyrenees across the Alps to the Carpathians, east to Ukraine (MAGNANO, 1953-1954; ALONSOZARAZAGA et al., 2013), i.e., in 19 European countries including Serbia's neighbours: Bosnia and Herzegovina, Croatia, Hungary, and Romania (Alonso-ZARAZAGA et al., 2017). The Global Biodiversity Information Facility (GBIF) has 536 georeferenced records from 1869 till 2020 (Fig. 1, GBIF SECRETARIAT, 2019a), but there no Balkan (except one from Galičica Mt. in North Macedonia), Ukrainian and Carpathian finds are present.

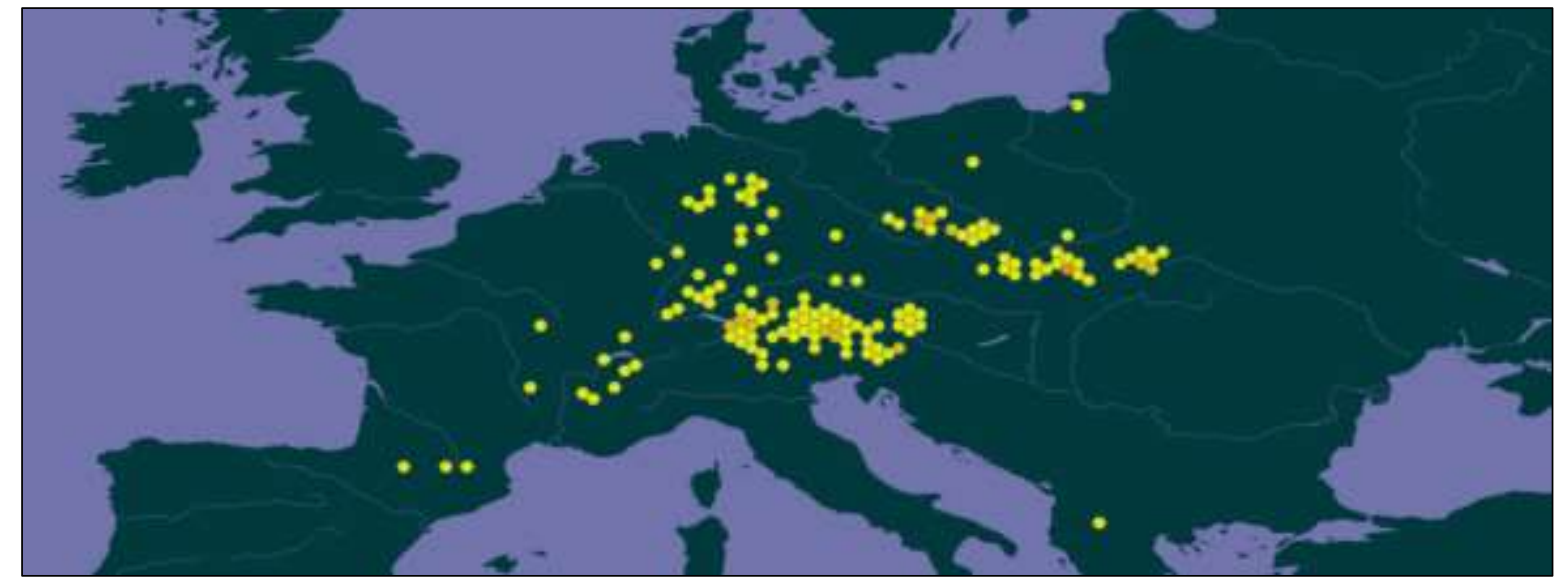

Fig. 1: GBIF georeferenced records of Liparus glabrirostris from 1869 till 2020 (https//www.gbif.org/species/5018172).

Although these are large insects and presumably easy for identification, the genitalia were extracted from both specimens (Fig. 3).

In addition to $L$. (L.) glabrirostris, two other species of this genus have been recorded in Serbia so far - three males of Liparus (Liparus) coronatus Goeze, 1777 in three localities on Mt. Fruška Gora (finds of 2003, 2006 and 2008, published in PEŠIĆ et al., 2017) and Liparus (Liparus) transsilvanicus Petri, 1895 (AlONSO-ZARAZAGA et al., 2017). 


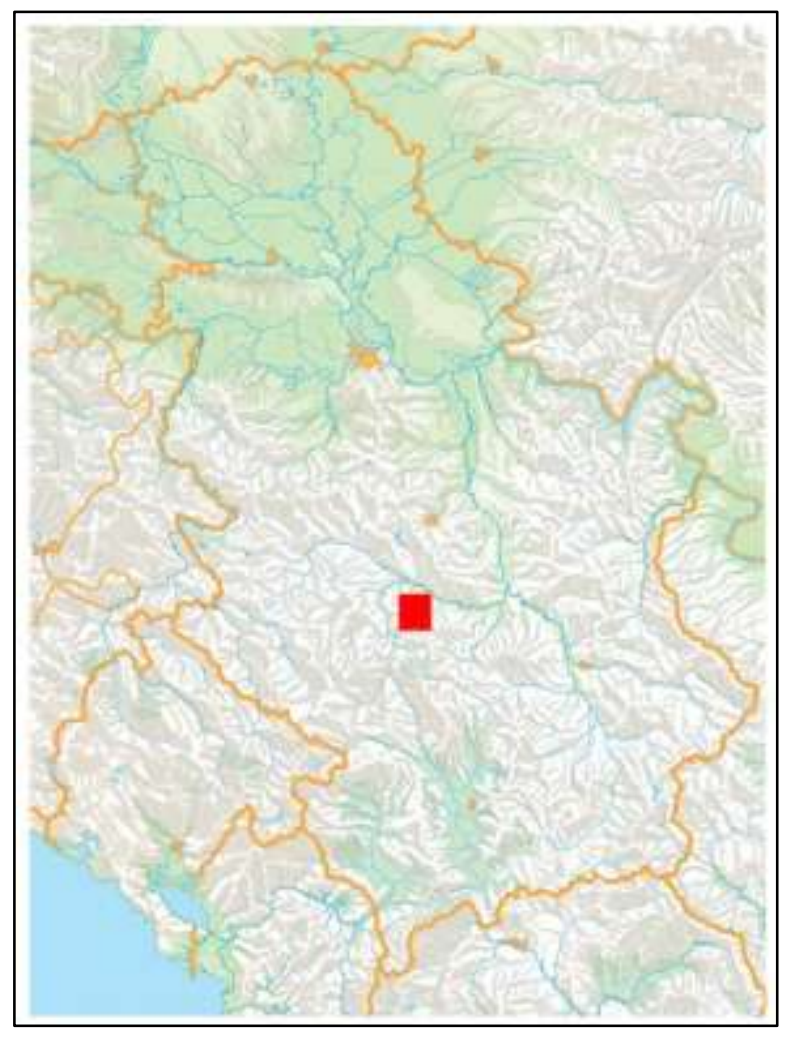

Fig. 2. Position of Goč Mt. in Serbia, where Liparus glabrirostris is registered.

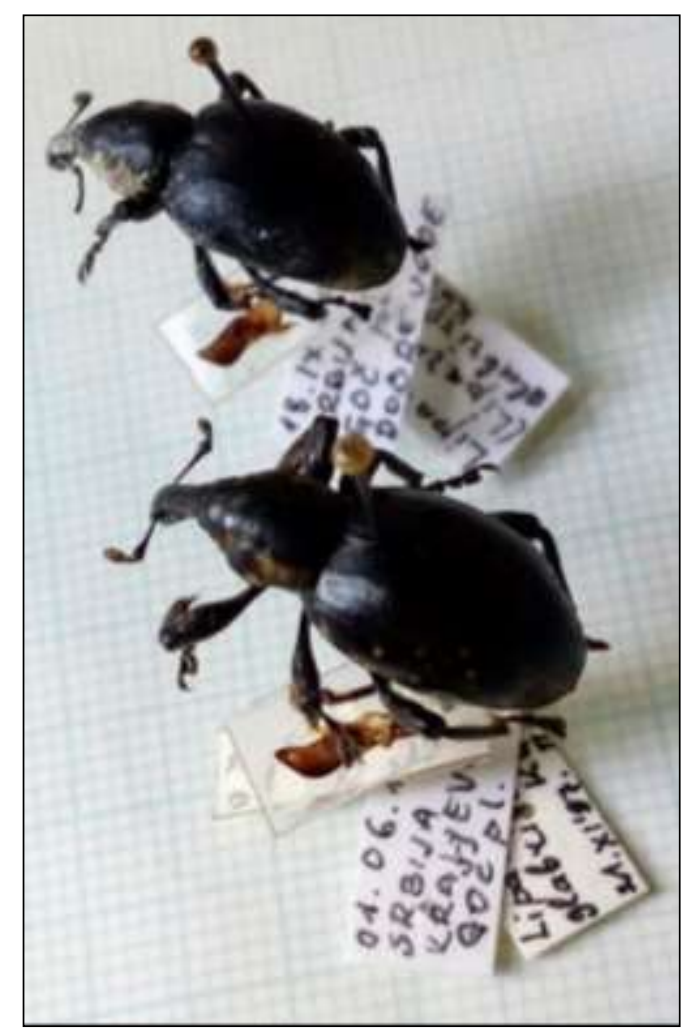

Fig. 3. Specimens of Liparus glabrirostris collected on Goč Mt. in Serbia, deposited in weevil collection at Faculty of Sciences, University of Kragujevac.

\section{A short key for distinguishing Liparus species registered in Serbia}

1 (4) Inner margin of fore tibia with small pointed or notched teeth.

2 (3) Femora strongly toothed. Antennal funicle robust; segments 3-6 wider than long. Pronotum finely and densely punctate, with basal edge curved, and yellow striped with hairlike scales. Two spots of yellow scales on the sides of the pronotum. Elytra slightly shiny, scal-like sculptured, with isolated small yellow spots. Body length 8.5-13 mm.

3 (2) Femora unarmed. Antennal funicle thin; segments 3-6 as long as wide. Pronotal basal edge straight, without yellow stripe. Pronotum with double punctation - with large, mostly flat-bottomed irregular punctures and fine and sparse punctures in between. Y-forked stripe of yellow scales on the sides of the pronotum. Elytra with numerous spots or bandages of yellow hairlike scales. Body length 14-21 mm.

glabrirostris

4 Inner edge of fore tibia finely granulate. Segments 4 and 5 of antennal funicle much wider than long. Femora obtusely-triangularly serrated. Elytra matt to glossy, indistinctly striate, with sparse yellow spotted pattern. Pronotum with indistinct median carina in anterior half. Body length 16-19 mm.

transsilvanicus

Since analysed populations of L. glabrirostris from fragmented habitats of Carpathian and Alps mountains ranges show no morphological differences, while genetically they form two well-differentiated groups (Mitrović et al., 2016), it will be interesting to analyse populations from Balkan Peninsula in the same way. 


\section{Subtribe Hylobiina W. Kirby, 1837 \\ Genus Hylobius Germar, 1817 \\ Hylobius (Callirus) abietis (Linnaeus, 1758)}

Hylobius (Callirus) abietis, one of the five European representatives of the subgenus Callirus, known as the large pine weevil, is another large weevil not recorded for Serbian fauna in the recent catalogue (ALONSO-ZARAZAGA et al. 2017), despite being listed in all local forestry textbooks as a very serious polyphagous pest of conifers (ŽIVOJINOVIĆ, 1948; ŽIVOJINOVIĆ et al., 1962; LAKATOS et al., 2014; BERASATEGUI et al., 2016; KEREŠI et al., 2016).

The body length of the large pine weevil varies from 6 to $16 \mathrm{~mm}$ (REITTER, 1891; ŽIVOJINOVIĆ, 1948; ŽIVOJINOVIĆ et al., 1962; ANGELOV, 1978; FREUDE et al. 1983; LAKATOS et al., 2014; KEREŠI et al., 2016). This species has interesting features, not so often found among beetle species from temperate climates. The developmental cycle of one generation lasts one or two years, while adults live more than two years depending on environmental conditions (ŽIVOJINOVIĆ, et al., 1962). Hylobius abietis is winged but flies only during the swarming period (April-May) (ŽıvoJiNOVIĆ, 1948).

This beetle occurs in coniferous and mixed forests at all altitudes (usually at logging plots: LAKATOS et al., 2014). The larvae cause very little damage, making holes in the root system of freshly felled trunks or in diseased trees, but the adults are major pests (ŽIVOJINOVIĆ, 1948). They can survive for three (ZAHRADNIK and SEVERA, 2000) or even up to six years (ŽIVOJINOVIĆ, 1948), damaging trees during feeding by gnawing the stems, twigs, or excavating the shoots (ROQUES et al., 2017), bark and roots, mainly on younger (2-6 years old) pines and spruces, causing death of young woods (LAKATOS et al., 2014). This weevil is polyphagous on a wide range of conifers, and feed also on some deciduous species (ŽIVOJINOVIĆ, 1948). The damage is particularly heavy on locations where there are stumps or freshly cut trees and saplings (LAKATOS et al., 2014). In Central Europe H. abietis is considered the worst insect pest of young conifers (HARDE and SEVERA, 2000; BERASATEGUI et al., 2016).

Hylobius abietis has respectable reproductive potential - with repeated mating, females constantly lay eggs from May to September in the bark of live roots of fir and spruce stumps (preferring stronger roots which protrude from the ground; ŽIVOJINOVIĆ, 1948), or freshly cut pieces of wood with bark (LAKATOS et al., 2014). A single female lays 60-120 eggs on average (KEREŠI et al., 2016).

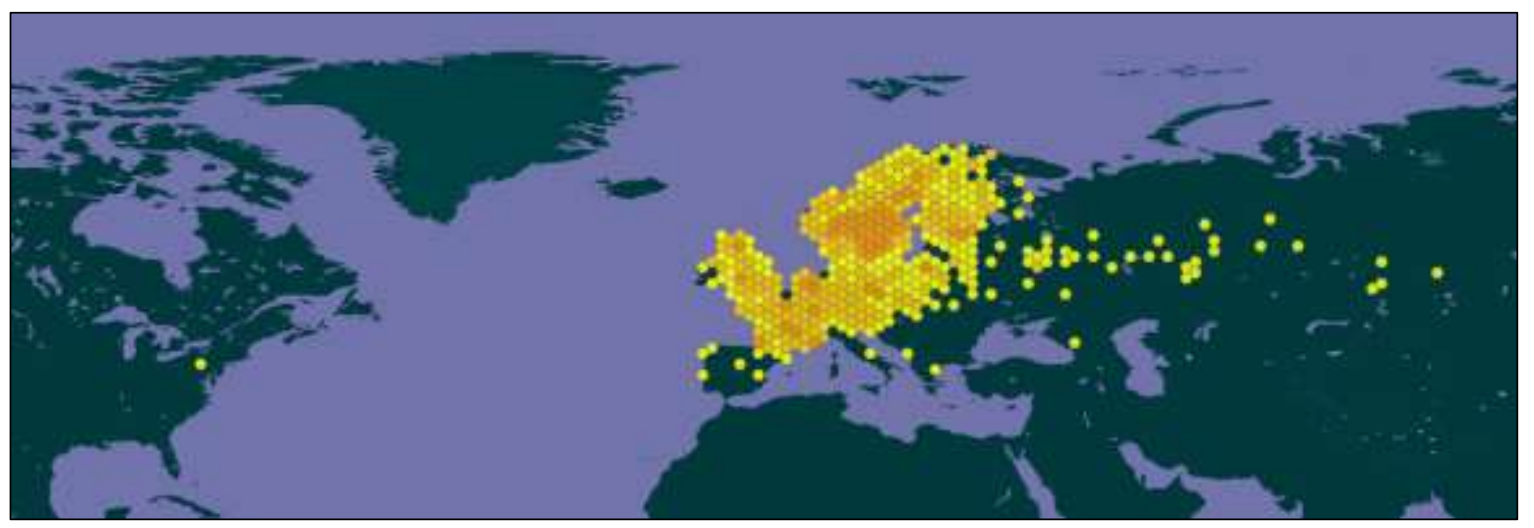

Fig. 4. GBIF georeferenced records of

Hylobius abietis from 1800 till 2020 (https//www.gbif.org/species/50214971).

The large pine weevil is widely distributed through Europe and Asia (ALONSOZARAZAGA et al., 2017), inhabiting practically all woods with Pinus (ANGELOV, 1976) and Picea abies (SMRECZYŃSKI, 1968), from the plains to the high mountains (ŽIVOJINOVIĆ, 
1948). GBIF has 9,878 georeferenced records of H. abietis collected from 1800 till 2020 (GBIF SECRETARIAT, 2019b; Fig. 3). This pest is also considered as invasive and included into the list of Centre for Agriculture and Bioscience International, but again, Serbia is not mentioned there (https://www.cabi.org/ISC/abstract/20066600643).

Except for the large pine weevil, one more species of the same subgenus has been recorded in Serbia earlier - Hylobius (Callirus) transversovittatus Goeze, 1777 (PEŠIĆ, 2014).

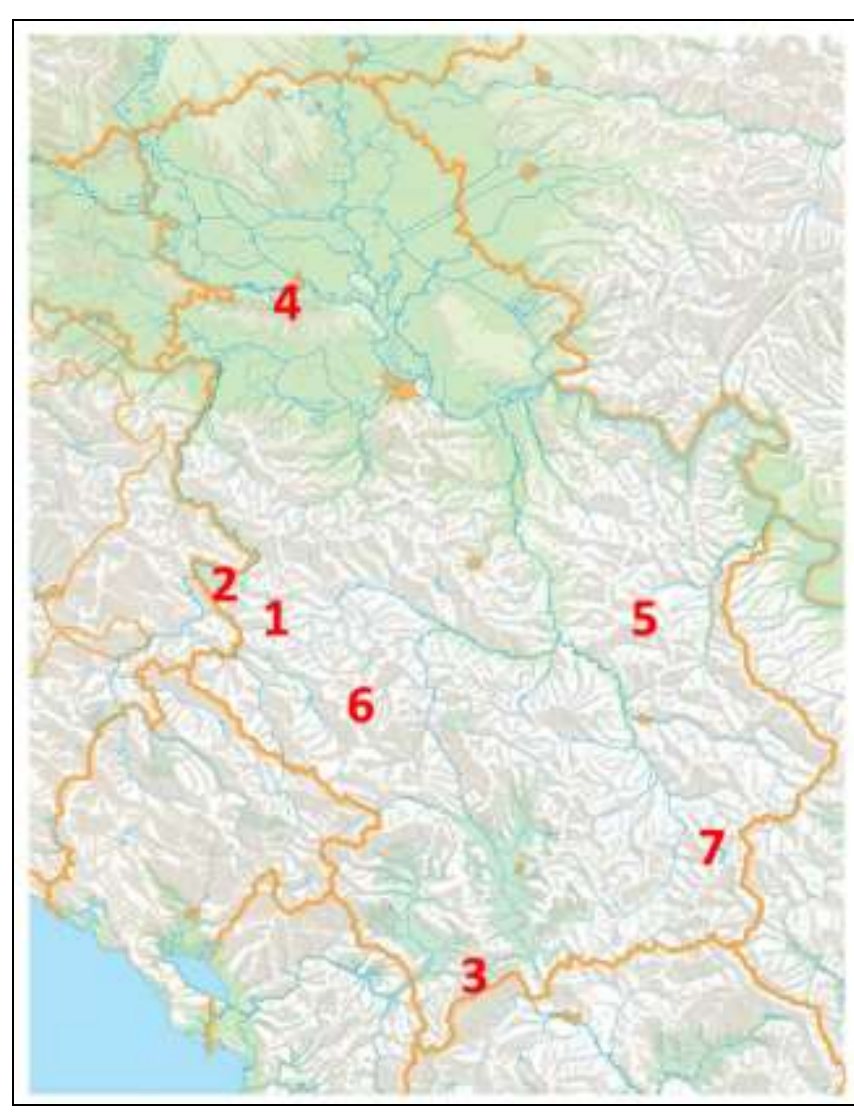

Figure 5. Locations of Hylobius abietis in Serbia: 1 - Zlatibor Mt., 2 - Tara Mt., 3 - Šar planina Mt., 4 - Fruška Gora Mt., 5 - Rtanj Mt., 6 - Golija Mt., 7 - Vlasina.

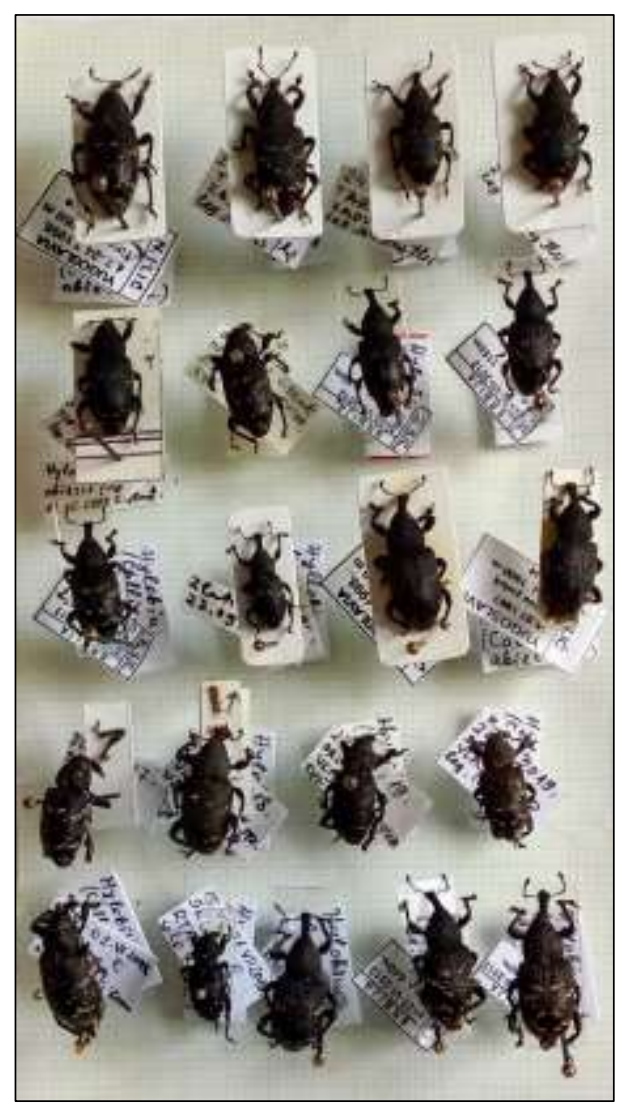

Figure 6. Specimens of Hylobius abietis collected in Serbia, deposited in the weevil collection at the Faculty of Sciences, University of Kragujevac.

\section{A short key for distinguishing Hylobius species registered in Serbia}

1 (2) Scutellum with noticeable yellow hairlike scales. Striae of punctures at bases of elytra as wide as interstriae or, in places, even wider. Granulation of elytra gradually disappears toward apices of the latter. Antennal funicle thin -2 nd segment as long as 1 st, 7 th segment not more than $1.5 \times$ as wide as long. Body and legs rust-red to red-brown. Elytra appearing quite bald and slightly shiny, with a few spots or bandages of yellow hairlike scales. Pronotum densely and very coarsely punctate (almost foveate). Body length 7.5-11 mm. Common around conifers, often at night.

transversovittatus

2 (1) Scutellum only inconspicuously hairy. Elytral striae at base narrower than interstriae. Granulation of elytra becoming finer toward their apices, but still well distinct. 7th segment of antennal funicle twice as wide as long. Body and legs dark brown to almost black. Hairs often interspersed, especially on pronotum and elytral base, with yellowish hairlike scales. Elytra less shiny, rather matt, with more spots or bands of yellow hairlike scales. Pronotum densely, but less coarsely punctate. Body length 7.5-13 mm. In peaty wetlands. abietis 
Obviously, without well collected and preserved material, a lot of faunistic data will be irretrievably lost to science. It is particularly important in the countries like Serbia, where nature is rich, while entomological collections, private or institutional, are very few. Such lack leads to potential loss of understanding of Serbian biodiversity and the possibility to conserve and manage this. Except it, thanks to the collections performing many kinds of taxonomic research is enabled.

\section{Acknowledgments}

Author expresses deep gratitude to reviewers for considerable improvement of the paper, as well as to all legators of the material: Vesna Stojanović, Ivo Karaman, Nastas Ilić, Dejan Stojanović, Ivan Tot and Mihailo Vujić. Material collected in 2017, 2018 and 2019 comes from the wider research projects realized by the Association for Sustainable Development and Habitat Protection in Serbia "HabiProt".

\section{References:}

[1] Alonso-Zarazaga, M.A., et al. (2013). Coleoptera 1, Curculionidae. Fauna Europaea Web Service, Version 2.6.2. Available online at https://fauna-eu.org/.

[2] Alonso-Zarazaga, M.A., Barrios, H., Borovec, R., Bouchard, P., Caldara, R., Colonnelli, E., Gültekin, L., Hlaváč, P., Korotyaev, B., Lyal, C.H.C., Machado, A., Meregalli, M., Pierotti, H., Ren, L., SÁnchez-Ruíz, M., Sforzi, A., SilfverBerg, H., Skuhrovec, J., Trýzna, M., Velázquez De Castro, A.J., Yunakov, N.N. (2017): Cooperative Catalogue of Palaearctic Coleoptera Curculionoidea. Monografías electrónicas S.E.A. 8: 729 pp. http://sea-entomologia.org/PDF/MeSEA_8_Catalogue_Palaeartic_Curculionoidea.pdf

[3] Angelov, P. (1978): Fauna na B'lgariya 7; Coleoptera, Curculionidae, II chast: Brachyderinae, Brachycerinae, Tanymecinae, Cleoninae, Curculioninae, Myorhininae. Sofia, Bulgaria: BAN. [in Bulgarian]

[4] Berasategui, A. et al. (2016): Data from: The gut microbiota of the pine weevil is similar across Europe and resembles that of other conifer-feeding beetles, Dryad, Dataset https://doi.org/10.5061/dryad.f3r67

[5] Germann, C., Bahr, F., Braunert, C. \& Link, A. (2018): Die Rüsselkäfer Griechenlands. Katalog der Curculionoidea Griechenlands (Coleoptera). - Le Charançon. Catalogues \& Keys No. 3, Curculio-Institute, Mönchengladbach. https://curci.site.at/en/taxons?view=plain\&q=hylobius+abietis\&commit=Search

[6] Freude, H., Harde, K.W., Lohse, G.A. (1983): Die Käfer Mitteleuropas; Band 11. Krefeld, Germany: Goecke and Evers Verlag.

[7] GBIF SECRETARIAT (2019a): Liparus glabrirostris Küster, 1849 in Global Biodiversity Information Facility (GBIF) Backbone Taxonomy. Checklist dataset. https://doi.org/10.15468/39omei accessed via GBIF.org on 2021-02-16.

[8] GBIF SECRETARIAT (2019b): Hylobius abietis W. Roelofs, 1873 in Global Biodiversity Information Facility (GBIF) Backbone Taxonomy. Checklist dataset. https://doi.org/10.15468/39omei accessed via GBIF.org on 2021-02-19. 
[9] HabiProt (2014-2020): Alciphron - baza podataka o insektima Srbije, http://www.alciphron.habiprot.org.rs Accessed 16 February 2021. https://alciphron.habiprot.org.rs/listing-257225-hylobius-abietis

[10] Harde, K.W., Severa, F. (2000): A field guide in colour to Beetles. Silverdale Books. 204 and $294 \mathrm{pp}$.

[11] Hoffmann, A. (1954): Faune de France; 59, Coleopteres, Curculionides (deuxieme partie). Federation Francaise des societes de sciences naturalles; Libraire de la Faculte des sciences, Paris: 487-1208.

[12] KerešI, T., SeKulić, R., Popović, A. (2016): Bolesti i štetočine u hortikulturi (Deo Štetočine u hortikulturi). Univerzitet u Novom Sadu, Poljoprivredni fakultet, Novi Sad: pp. 131-132. [in Serbian]

http://polj.uns.ac.rs/sites/default/files/udzbenici/Bolesti\%20i\%20\%C5\%A1 teto\%C4\%8

Dine $\% 20 u \% 20$ hortikulturi\%20\%28deo\%20\%20\%C5\%A1teto\%C4\%8Dine\%20u\%20hortikulturi\%29.pdf

[13] Lakatos, F., Mirtchev, S., Mehmeti, A., Shabanaj, H. (2014): Glavne šumske štetočine na vrstama drveća od privrednog značaja u Jugoistočnoj Evropi. Organizacija za hranu i poljoprivredu Ujedinjenih nacija (FAO), Priština: pp. 29-30. [in Serbian] https://www.scribd.com/document/369650337/glAVNE-STETOCINCE-pdf

[14] LOMPe, A. (after G.A. LoHSE) (2013): Die Käfer Europas - Ein Bestimmungswerk im Internet. http://coleonet.de/coleo/texte/hylobius.htm

[15] Lompe, A. (after H. KipPenberg, E. ReitTer) (2018): Die Käfer Europas - Ein Bestimmungswerk im Internet. http://coleonet.de/coleo/texte/liparus.htm

[16] Magnano, L. (1947): Alcune note sulla sistematica e sulla distribuzione geografica delle specie appartenenti al genere Liparus Oliv. Memorie del Museo Civico di Storia Naturale, Verona 1: 141-163.

[17] Mitrović, M., Tomanović, Ž., Jakovljević, M., Radović, D., HavelKa, J., Stary, P. (2016): Genetic differentiation of Liparus glabrirostris (Curculionidae: Molytinae) populations from the fragmented habitats of the Alps and Carpathian Mountains. Bulletin of Entomological Research 2016, 12 pages doi:10.1017/S0007485316000377

[18] NAZARENKO, V.YU. (1996): O stroenii rudimentov krylev zhukov-dolgonosikov roda Liparus Olivier (Coleoptera, Curculionidae). Entomologicheskoe obozrenie LXXV (1): 113-116. [in Russian] https://www.zin.ru/ANIMALIA/coleoptera/pdf/nazarenko1.pdf

[19] NaZARenko, V.Yu. (2001): Contribution to the morphology of old-stage larva of the weevil Liparus glabrirostris (Coleoptera, Curculionidae). Vestnik zoologii, Kiev 35 (1): 59-62. [in Russian]

[20] PEŠÍć, S. (2002): Weevils (Curculionoidea) of the National Park Tara (the first contribution). Acta entomologica serbica 7 (1/2): 29-39.

[21] PEŠIĆ, S. (2014): A review of weevils (Coleoptera, Curculionoidea) in the Zasavica Special Nature Reserve (Serbia). North-Western Journal of Zoology 10 (2): 280-292.

[22] Pešić, S., Stojanović, V.D., Savić, D. (2017): Weevil fauna (Coleoptera: Curculionoidea) of the Fruška Gora Mountain. - In: Invertebrates (Invertebrata) of the Fruska Gora Mountain (ed. Šimić, S.). Matica Srpska, Novi Sad: 5-46.

[23] ReitTeR, E. (1891): Uebersicht der europäischen Arten der Coleopteren-Gattung Hylobius Sch. Wiener Entomologische Zeitung 10 (3): 97-98. 
https://www.zobodat.at/pdf/WEZ_10_0097-0098.pdf

[24] ReITter, E. (1916): Fauna Germanica: Die Käfer des Deutschen Reiches, V. Band. K. G. Lutz' Verlag, Stuttgart: 109-111 p.

http://publikationen.ub.uni-frankfurt.de/frontdoor/index/index/docId/9219

[25] ReITTER, E. (1923): Die Liparus -Arten aus Europa und den angrenzenden Gebieten. (Col. Curcul.). Wiener Entomologische Zeitung 40 (1-4): 42-48.

https://www.zobodat.at/pdf/WEZ_40_0042-0048.pdf

[26] Roques, A., Cleary, M., Matsiakh, I., Eschen, R. (2017): Field Guide for the Identification of Damage on Woody Sentinel Plants. CAB International. 292 pp. https://www.cabi.org/forestscience/ebook/20173265430

[27] Skuhrovec, J.,Caldara, R., Stejskal, R.,Bahr, F.,Trnka, F., Gosik, R. (2013): Digital-Weevil-Determination for Curculionoidea of West Palaearctic. Brachycerinae (Brachycerini, Erirhinini \& Tanysphyrini). - SNUDEBILLER: Studies on taxonomy, biology and ecology of Curculionoidea, Curculio-Institute: Mönchengladbach 14, 215: 17 pp. https://www.researchgate.net/publication/260835378_Digital-Weevil-

Determination_for_Curculionoidea_of_West_Palaearctic_Brachycerinae_Brachycerini_ Erirhinini_Tanysphyrini

[28] SMreCZyŃski, S. (1968): Klucze do oznaczania owadów polski; część XIX: Chrząszcze - Coleoptera, zeszyt 98c: Ryjkowce - Curculionidae; podrodziny Tanymecinae, Cleoninae, Tanyrhynchinae, Hylobiinae. Polskie Towarzystwo entomologiczne, Warszawa: 106. [in Polish]

[29] ZaCwILICHOWSKI, J. (1931): Unerwienie skrzydel owadów. Rozprawy Wydzialu Matematyczno-Przyrodniczego, Kraków $70 B$ (III 30) 2: 56. [in Polish]

[30] Zahradnik, J., Severa, F. (2000): A field guide in colour to Insects. Silverdale Books. 204 and $206 \mathrm{p}$.

[31] ŽIvoJINOvić, S. (1948): Šumarska entomologija. Naučna knjiga, Beograd. 352 pp. [in Serbian]

[32] Žıvojinović, S., Vasić, K., Spaić, I., Petrović, N. (1962): Zaštita četinara. Jugoslovenski savetodavni centar za poljoprivredu i šumarstvo, Beograd. 192 pp. [in Serbian]

[33] https://www.cabi.org/ISC/abstract/20066600643 